一捴 説

飼料中のグルコシノレートと家畜・家离への影響

松 本 達 郎

東北大学農学部, 倠台市 980

\title{
Glucosinolates in Feeds and Effects on Performance in Livestock and Poultry
}

\author{
Tatsuro Matsumoto \\ Faculty of Agriculture, Tohoku University, \\ Sendai-shi 980
}

ダルコシノレート (glucosinolates) は，以前はカラシ 油配精体 (mustard oil glucosides) とか，含硫配糖体 (thioglucosides) と呼ばれていたもので，ナタネ子実中 では柔組織 (parenchymal tissues) に庆く分椎してい る. glucosinolates 爷分解する䤃素 myrosinase は, 三 ロシン細胞（myrosin cell）乙呼代れる特定の異形細胞 内にあって，植物体内では陑者は隔離されて在してい るが，子実の細胞がこわされ，水分含量が充分である 之，この醉素が作用して glucosinolates が分解し，グル コースと酸性硫酸イオンを遊離する一方, oxazolidinethione (OZT, ゴイトリ), isothiocyanate (ITC, カラシ 油)，alkyl-cyanamide (nitrile, ニトリル)などを生成す 方.

\section{ミロシナーゼによるグルコシノレート の加水分解}

擢油の際にナタネ子実を押し瀆すと，myrosinase が働 いて glucosinolates の一部が分解寺るが，大部分仿その ま油粕中に残存する. 加憼処理が充分行なわれてい度

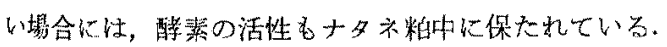
glucosinolates 省九だナタネ粕に水が加わり，myrosi一 nase 加作用す百昜含，飞の条件によって分解生成物の 種類や量加変化する. HILL'1は，加熱していないナタネ

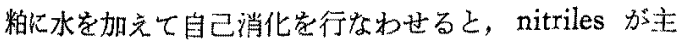
で OZT の少い加水分解加生成与るのに対し，予め加熱 処理をしてナタネ自体に含まれていた myrosinase 它不
活化した後，改めて新たにカラシの myrosinase 老添加

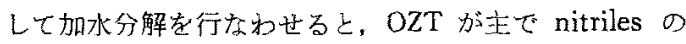

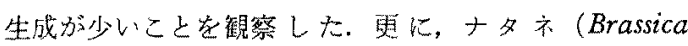
napus）の myrosinase 它作用させた場合上，白力シシ (Sinapus alba) の myrosinase 学作用させた場合とを比 較したところ，白力ラシの myrosinase 走用いたときの

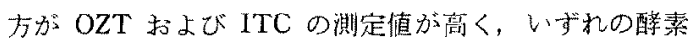
を用いた埸合む，フスコルビン酸（AsA）を添加した場 合の測定值は，添加せずに測定した值に比べて高くなっ た。特に，ナタネの myrosinase 老用いた場合は，AsA

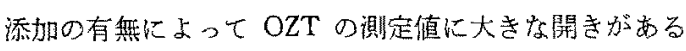
ことを磼かめている. myrosinase にAsA 添加すると myrosinase の活性が著しく增大寸る現象は，1957 年に

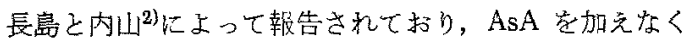
ても活性をもっているものと，AsA を加えなければほ

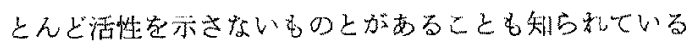

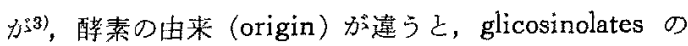
加水分解反忘之のものが異なるのかどうか，今後更に詳 細に検討する必要がある。最近 MELVIN口仿，ナタネ と極めて近縁な植物であるキャベッ (Brassica oleracea)

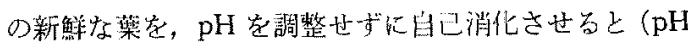
5.6〜6.3), 主として nitriles 生成し，同じキャベッを 一旦風乾した後 $\mathrm{pH} 5.8 \sim 6.3$ で自己消化させると，主

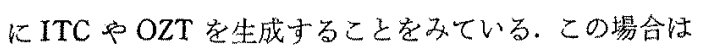
同じ由来の酵素它，同し glucosinolates に作用させてい るのでるが，徍かな姏理の違いで，をの分解生成物が 
異なること宗するのとして注月される。

myrosinase はカラシやワサビなどの辛枺老生成させ る酸素として古く各ら知られており，アブラナ科（Cru-

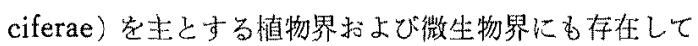
いる. 当初は myrosine または sinigrinase と名付けら れていたが，最近は glucosinolase とも㭔ばれている。 International Union of Biochemistry $D$ 命名規則に従う と, 亚式には thioglucoside glucohydrase (E. C. 3.2.3. 1.）と記すととになっている. myrosinase に関する最近 の知見をとりをとめたものとして大鹤索の総説がある が, glucosinolates k対与る myrosinase の反応機满, な らびにとの分解生成物に関して，今後の研究の進展にま たねばならない点が多いようでする。

1. ゴイトリン

アブラナ屬 (Brassica) 植物の子实学ラットに給与す ると甲状腺が肥大することを KENNEDY and PURVES ${ }^{5)}$ 范 報告したが,AsTwood et al. ${ }^{6}$ は、アフブラナ属植物の子実お よび菜から抗甲状腺作用のある物質を単離し，その化学

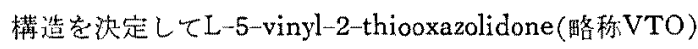
と命名した。矢の後 (-)-5-vinil-2-oxazolidinethione たは (-)-5-vinyloxazolidine-2-thione (略称 OZT) 上改 名され，之の抗甲状腺作用に基ういて goitrin という呼

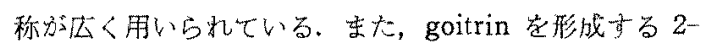
hydroxy-3-butenylglucosinolate られており，progoitrinより goitrin の形成経路は次の 様涪交られている。

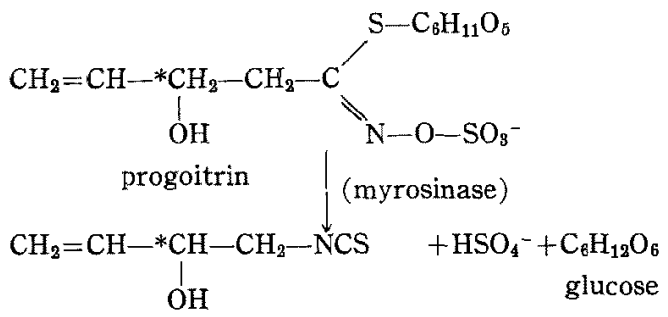

2-hydroxy-isothiocyanate

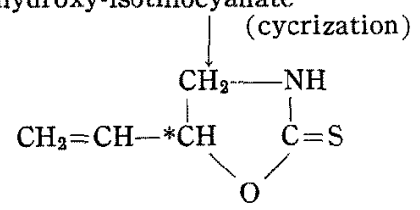

5-vinyl-oxazolidine-2-thione (OZT, goitrin)

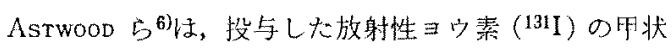
腺内人のとりこ双䏣害老指橪にして goitrin 0 抗甲状腺

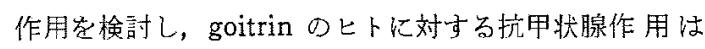
thiouracil (TU) と等しく，ラットに対しては TU の 1/5であったと述べている。しかし，goitrin 左期間
ットに投与した埸台，体重に刘する甲状腺重量の比注著 しく增大したが，181Iの甲状腺心のとりこみについては， 対照区と差がなかったという赫告7,8 むあり，抗甲状腺作 月の強さの比校は，単純には行な夫ないようである。

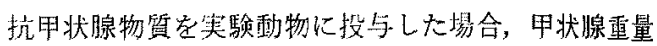
が漖しく增大するのは，抗甲状腺物質が甲状腺における

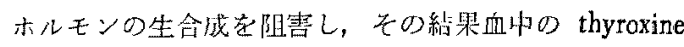

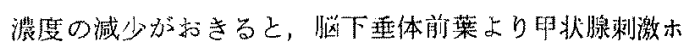
ルモン（TSH）の分泌怔增加し，これが甲状腺を剩激し て甲状腺重量家增加さ甘るものと考えられている9. 抗 甲状腺作用の強さ学比故する場合，ヨウ瑟のとりこみ阻 害を指標にするが，甲状腺の重量增加を指標にするか， 甲状腺内の木ルモン生合成に対与る阻害を指標に与る

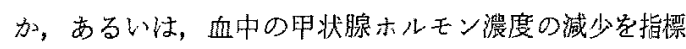
にする加比よって，抗甲状腺作用の誰传異なってく る. АкIBA and Matsumoto ${ }^{10}$ は, 白レグ雄初坐ヒナに goitrin または propylthiouracil (PTU) 究段階的に種々 異なった水準で添加した飼料を14日間給与し，14日令 に Na ${ }^{131} \mathrm{I}$ 注射乙て goitrin \& PTU O抗甲状腺作用 を parallel-line assay によって検討した. goitrin の肰 腺肥大作用は PTU の約 1/3，血中の甲状腺木小モ之濃 度壱減少させる作用で怯 PTU の $1 / 10 \sim 1 / 15$, 甲状腺 内でのホルモン生合成觉阻害ず尚作用注 PTU の 1/20 〜1/25 という結果を得た。 なお， ${ }^{131}$ I の甲状腺へのとり こみ阻害作用については，PTU は ${ }^{181}$ のとりこみを減 少させたが goitrin は逆にとりこみを增加させたので， この指嫩を朋いて两者の抗甲状腺作用を比較することは 出来なかった. ClANDININ ら“は，合成 goitrin（ラセミ 体）を用いて，ヒナの成長，甲状腺重量，甲状腺の ${ }^{131} \mathrm{I}$

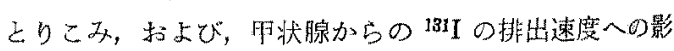
䇾を調べた。 goitrin 飼料に添加したことによって， 最初は甲状腺の ${ }^{131}$ とりこみ为減退し, 甲状腺からの排 出速度の方は早められたが，3〜4 週間経過すると，131I の己りこ欢が増加し，田状腺吕らの排出速度は正常に復 した. goitrin を提取したとナでは，体悬に対ずる阵 腺重量の比が增加したまを生理的非衡状態に到達したも のと考えられると述べている. goitrinまたは PTU 艺 $10 \mathrm{mg}, 1$ 日 2 回, 3 日間連続してヒナの筋肉内に注射し た AkIBa and Matsumoto ${ }^{12}$ の奏験では, goitrin \& PTU

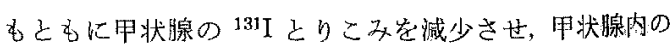
ホルモン合成定抑制し，血獎山の $\mathrm{PB}^{131} \mathrm{I}$ 濃度范低下さ 世た。この場合の抗甲状腺作用について性，goitrin と PTUとの間に差がなかった. $30 \mathrm{mg} の$ goitrinまたは PTU を, 微アルカリ性水溶液として, 2 週令の白堭 雄ヒナに1回だけ経口投与した場合 ${ }^{13)}$ は，goitrin 投与 


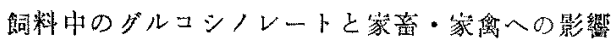

後抗甲状腺作用発現をでの侍間が，PTU に比较して長 くかかり，その作用の消失するまでの㭙間性 goitrinの 方放早加。た。

成長中のヒナに goitrin, methimazole (1-methyl-2 mercaptoimidazole) および methiocil (6-methyl-thiouracil) の3種の抗甲状腺物筫を泀料に $0.05 \%$ 潦加して 3 週間給与し，甲状腺の ${ }^{131}$ I とりこみと排出艺比数し た Matsumoto $ら^{14)}$ の实験によると，goitrin 添加の場合 は，甲状腺の単位重量索たりの ${ }^{131}$ とりこみは抗甲状腺

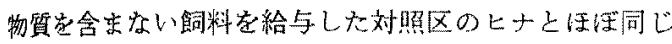

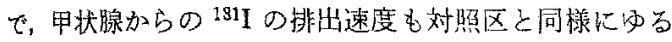
やかであった. methimazole あるいは methiocil 添添 した区では，甲状腺の単位重量あたりの ${ }^{131}$ エの上りこみ 肪，对照区あるいは goitrin区の約 $1 / 2$ となり，甲状腺 加らの排出速度は対照区よりむ早くなった。この場合， goitrin 添加区の甲状腺重量は刘照区の約了倍になって いて, ${ }^{13} I$ のとりこ我総量としては goitrin 区は詨照区 の約3倍の值を示した.

甲状腺ホルモンは，循環血より䑤機態のヨウ素イオン を甲状腺内の thyroglobuline 分子内にとり入れて，ここ て酸化酵素系の働きによってヨウ素と tyrosine と起絬 合させて monoiodotyrosine (MIT) および diiodotyrosine (DIT) 老生成し， 2 分子の DIT が縮合して thyroxine $\left(\mathrm{T}_{4}\right)$ 作り，1 分子の MIT と 1 分子の DIT と 加維合して triodothyronine $\left(T_{3}\right)$ を生成するものと考 えられている \%添加した飼料を給与したヒナに Na ${ }^{1311}$ 在投与して, 甲状腺ホルモンの生合成に対する影響を比渂したAKIBA and Matsumoto ${ }^{10.16 .17}$ の实験によると, PTU は中状腺 ホルモンの生合成の全ての段階起抑制するのに効して， goitrin は甲状腺ホルもンの生合成芫阻害するが，コウ 素イオンの酸化括よび MIT の生成は阻害しない. しか $l$ ，甲状腺内の iodothyronine $\left(\mathrm{T}_{3}+\mathrm{T}_{4}\right)$ の低下加比較 的少ない割には，血中のホルモン莀度の低下が幾分大主 いことは, goitrin が印状腺ホルモンの分泌機能に何ら

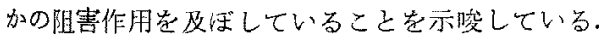

Lo and HrLL ${ }^{18}$ は, glucosinolate 含量の低いナタ秥 (Bronowski meal) と合量の高いナタ稍 (B. napus meal) とを用いて，跼粫中の glucosinolates 食鼠が 0.3 \%のものと，2.6\%のもとを調製し，この二種類の飼 料の掫取毁が同一になるように制限給慨した場合のラッ

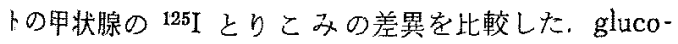
sinolates の摄取量务少以場合に怙，柙状腺の单位重量あ たりの ${ }^{226 I}$ のとりこみが增加したが, glucosinolates の

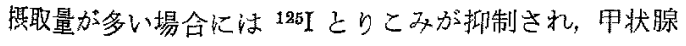

内で門機ヨウ秦の有機化が阻害されたと報告している。

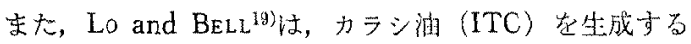
3-butenyl-isothiocyanate 型の glucosinolate (ITC)-G と，ITC と OZT の闻者党生成するナタネの glucosinolate [(ITC) $-\mathrm{G}+(\mathrm{OZT})-\mathrm{G}]$ 荤21 $\mathrm{E}$ 間ラットに給与し,

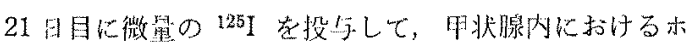
ルモン合成への影蒩を調へた。(ITC) - $\mathrm{G}$ の投与は ${ }^{125} \mathrm{I}$ $\mathrm{T}_{3}$ おるび ${ }^{125} \mathrm{I}-\mathrm{T}_{4}$ の割合学隇少させ，[(ITC)-G+ (OTZ) -G]の給与では，甲状腺内のヨウ素の大部分がヨ ウ菜イオンの幵で存在し，(125I-T $\left.\mathrm{T}_{3}+{ }^{125} \mathrm{~T}-\mathrm{T}_{4}\right) /\left({ }^{125} \mathrm{I}-\mathrm{MIT}\right.$ +125I-DIT) の比率加低下すること考灭ている. Lo and HrL2 ${ }^{20}$ 惊, myrosinase を不活化したナタ亦粕中の glu一 cosinolatesおよびナタネ粕から抽出分離した glucosinolatesをママウス执よびラットに給与して，消化管内で， glucosinolates が分解昰たは吸取されることを碓からて

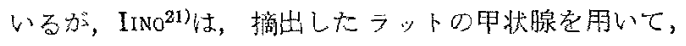
甲状腺ホルモンの in vitro 生合成に対スる抗甲状腺物 質の阻害作用を梌討し，goitrin は甲状腺ホルモンの生 合成阻害するが， progoitrin は何方抗甲状腺作用定

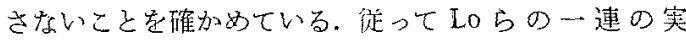
験 18-20) は, glucosinolate ぶラットの消化管内で分解さ れ，ての分解物方吸取されたことを示㙀しているるの上

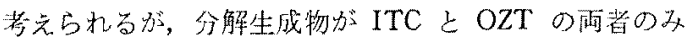
であったかどうかは朋らかでない. SMITH and CAMP-

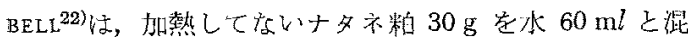

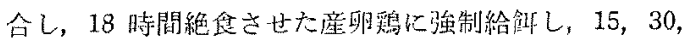
60 分後に屠袂して消化管各部の内容物を洞べたとこる， nitriles は消化管内の全城に亘って存在し，它の量 は OZTよりも多かったと記している.ナタネ粕中の gluー cosinolates が消化管内で加水分解した際の生成物には nitriles が多いということは注目すべき䇺实であるが， 前述の HILL ${ }^{1)}$ 実験絬果もこれを裹瑟している。

GREER and DEENEY'23) rin 㹥 myrosinase を同特に与えなくとも，ほとえど定 星的に goitrin k变化するので，加熱に上り myrosi nase 不活化すれ佂 glucosinolates 釜むアブラナ科

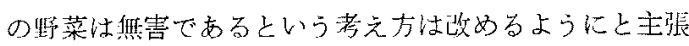
しているが，ヒナの䝭料に配合したナタ不粕の轨甲状腺

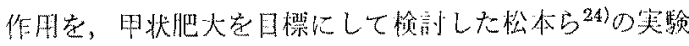
によると，ナタ不粕の抗甲状腺作用は，化学的に定量さ れた goitrinの存在量から予測されるものよりはるかに 小さい. 往って，七ナの消化管内でナタネ粕の glucosi-

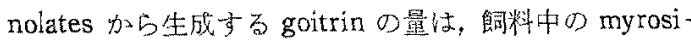
nase 活性さえ除かれていれば，極好て僅かであると考

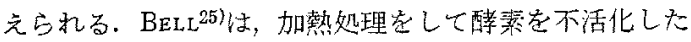


ナタ神粕を配合した飼料を豚に与えた場合これに myrosinase の供給源となるもの添加すると，添加し ない場合に比べて，成長阻蹇が 3 倍も大きくなることを

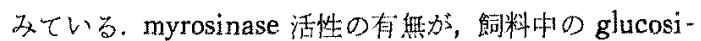
nolate の生理作用の発現に大きく関与しているとと示 唆しているものと考えられる。

生体内にとりこをれた goitrin の代謝については， PeLTOLA and KrusIUs ${ }^{26)}$ が，放射性イオン $\left({ }^{35} \mathrm{~S}\right)$ で標識 した goitrin をラットに投与して，四状腺，胡臟および 腎䁍へのとりこみを調べている. goitrin む他の抗甲状 腺物筫，PTU ○ methimazole などと同じく，特に甲状 腺内に多くとりこまれ，甲状腺からの排出速度は他の葴 器に比べてゆるやかである. 従って, 1 日あたりの goitrin の掑取量が少くてあ，長期間に亘って摄取すれば， 甲状腺红何らかの影響をむたらす場合も古りうると鳖告 している.

甲状腺ホルモンは動物体の全般的な物質代謝定盛に し, 発育已成熟定促進する作用があるので，抗甲状腺物

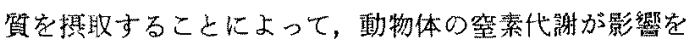
受けること少予想される。 BELL ${ }^{2 \pi}$ は，飼料に $0.15 \%$ の goitrinを添加した場合，マウスの成長が良質な飼料を 与えた標淮的成長の約 $1 / 2$ に低下したことを報告してい る. 林ら ${ }^{28}$ 泩，種々の異なった量の goitrin をラットに 経口投与して，吕素代謝への影響を検討した：未成熟亏 ッの場合就 goitrin の投与比よって空菜蓄積量が減少 したが，成熟ラットの場合は逆に增加した。飼料に 0.05 \%の goitrin 学添加して成熟ラットに給与した秋葉・松 本 ${ }^{291}$ の飼養䟼験では，飼料のエネルギーおよび粗タンパ 夕質の消化率は goitrin を添加しても变化しなかった

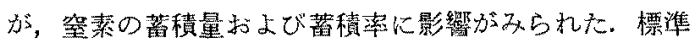
タンハタク質飼料 (CP 16\%) 給与の場合, 窒素の蓄棈量 および蓄積率が goitrin の添加によって有意に增加した $(\mathrm{P}<0.05)$. しかし，低タンパク質飼料（CP 5\%）の場 合は, goitrin 無添加の対照区よりも飼料の掑取量が減 少し, 窒素の蓄樍量および蓄積㵏がともに有意に減少し た $(\mathrm{P}<0.01)$.

動物体の堂素代謝に対する goitrin の影響は，投与量 によっても異なるが，動物の幼苦と成熟の違い，饲料中 のタンパク質の含量の多い少いによって，大きく変化す ることが確かめられた。

\section{2 , カラシ油とチオシアン化物}

isothiocyanate (ITC) は, カラシ油 mustard oil と呼 ばれる揮発性の辛味成分で，調味料として用いられる力 シシに江多量に含まれている，独特の刺战臭在有するの で，ナタネ粕中に遊離の形で存在する場合は，たと六微
量であって子容易に感知出来る，有機溶剂に可溶である から，正抽法をたは抽出法で採油したナタネ粕には，遊 離のITC はほとえど存在していない。

BELL ${ }^{30}$ 法, ITC (allyl-isothiocyanate) を大豆粕拉よび 肉粉に $0.05 \%$ 添加してマウスに給与した場合，飼料採 取量安同一量に補正した体重の增加量が，ITCを添加し ない対照区に比べて $12 \%$ 減であったと述べているが，ナ タネ粕を $10 \%$ 配合した育能用解料に，更に0，05\%の ITC を, 給䬣の都度飼料に添加して白レグ雄初生ヒナに 35 日間給与した伊藤ら ${ }^{31}$ の飼養試験では, ITC 添加区 の飼料法カラシ油真が非常に強烈であったが，飼料摄取 は良好で，ヒナの発育は ITC 然添加のナタネ粕区より

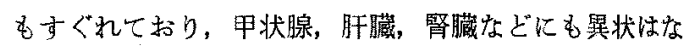
加た.

新鮮なキャベッの菜をウサギに多量給与すると，甲状 腺が肥大することが知られており，cabbage goiter と名 付けられているが，キャベッに含まれている抗甲状腺物 質は主に thiocyanate であり， thiocyanate による甲状 腺の肥大恃, ヨウ素の添加によって防止で变る ${ }^{32)}$. thiocyanate は中状腺のヨウ䒧のとりこみを妨代るが， 充分量のヨウ素が方れば，たと之 thiocyanate 放飼料に 含まれていても，甲状腺ホルモンの生合成は正常に行な われる。しかし，ナタネ粕給与によっておこる甲状腺の 肥大は，ヨウ素を添加しても防止はできない33-377.

Langer ${ }^{88,399}$ は，キャべッの抗申状腺作用は，thiocyanate, goitrin および ITC 3 者の複合作用と結諭してい る.

カラシ油は isothiocyanic acid のエステルであるが， 遊離の isothiocyanic acid と thiocyanic acid の両者は, 分子内転位によって相互に変化する互変異性体である.

$$
\mathrm{H}-\mathrm{N}=\mathrm{C}=\mathrm{S} \rightleftarrows \mathrm{H}-\mathrm{S}-\mathrm{C} \equiv \mathrm{N}
$$

isothiocyanic acid thiocyanic acid

多くのアプラナ科植物で， isothiocyanate の代わりに thiocyanate が存在していることが確かめられている が40)，ナタネの場合はカラシと同様に ITCが多い，甲状 腺に対する ITC の作用を OZT と比較した松本ら ${ }^{24)}$ 実呀では，ITC 投与による甲状腺の肥大は漌かであった が，ITC は甲状腺の ${ }^{131}$ とりこみに対して抑制的に作 用し，OZT は羊に促進的作用した. ITC と OZT と 芯同特に与えた場合性，ITCの抑制作用はOZT D促進 代用によって打消された。

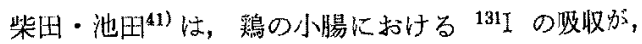
thiocyanate (KSCN) Kよって抑制されるが methylthiouracil (MTU) で注影響がないことをみている. AkIBA and Matsumoto ${ }^{42)}$ 仗 goitrin $0.05 \%$ 添加した 


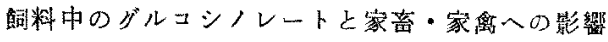

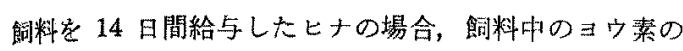
見掛忛の吸收䇣は goitrin 定添加していない対照区と同 じであった，以上の結果はthiocyanate の抗甲状腺作用 はヨウ素の添加によって防止出来るが，goitrin による 甲状腺の肥大はヨウ素を添加してをあまり效果汃ない事 实と関連があるものと考えられる。

\section{3. ニトリル}

glucosinolates の分解生成物のうち, nitriles Kつ々的 の研究報告は比較的少い，しかし，支の害作用という点 ては最す注目すべき物筫のように考えられる。 VANETTEN ら ${ }^{431}$ 俚，ナタネ之同じブラナ科の植物である crambe (Abyssinian kale) の子実より抽出した glucosinolates 㞱 myrosinase によって加水分解し, 3 種類 の nitrile と goitrin との混合物を得た。この nitrileを 飼料に添加してラットに与えるとその害作用は goitrin より名大きく，成带加愠害され，死亡が多くなることを みている. 最近 HILL'は, nitrile が多くgoitrin の少い ナタネ粕 (nitrile $5.67 \mathrm{mg} / \mathrm{g}$, goitrin $1.80 \mathrm{mg} / \mathrm{g}$ ) と nitrile 加少く goitrin の多いナタ稍 (nitrile $0.29 \mathrm{mg}$ / g, goitrin $8.40 \mathrm{mg} / \mathrm{g})$ とをラットおよびヒナに給与し てとの影響を比較したが， nitrile goitrinに比べて害 作用が強いことを確かめている。 また，ヒナに対して は, myrosinase を添加して与えれば寒作用を示すが, myrosinase 羍添加しなけ扎ば害作用を示さなかったナ タネ䊉が、ラットに対しては, myrosinase 学添加しなく ても著しい成長阻害を示したこと老報告している。この こと性飼料作 myrosinase がなくても，ラットでは消 化管内で glucosinolates の分解が行なわれるが，ヒナで はその分解が少いととを示㙏与るものと解される。

nitrile は反心性に富えボ化合物で $-\mathrm{C} \equiv \mathrm{N}$ 結合の存在 に基く多くの附加反応が知られているが，酸またはフル カリによって加水分解され，第一段觜ではマミド在作 り，ついで，酸とアンモニアを生成する。

$$
\mathrm{R} \cdot \mathrm{CN} \stackrel{\mathrm{H}_{2} \mathrm{O}}{\longrightarrow} \mathrm{R} \cdot \mathrm{CO} \cdot \mathrm{NH}_{2} \stackrel{\mathrm{H}_{2} \mathrm{O}}{\longrightarrow} \mathrm{R} \cdot \mathrm{COOH}+\mathrm{NH}_{3}
$$

nitrile が罡元されると，第一段階ではイミンを生成 し; ついで, 第一アミンとなる.

$$
\mathrm{R} \cdot \mathrm{CN} \stackrel{2 \mathrm{H}}{\longrightarrow} \mathrm{R} \cdot \mathrm{CH}=\mathrm{NH} \stackrel{2 \mathrm{H}}{\longrightarrow} \mathrm{R} \cdot \mathrm{CH}_{2} \cdot \mathrm{NH}_{2}
$$

ナトリウムとナルコールによる邆元では，产易に第-... フミン安生成子る任か，副次的に炭化水素とシアン化水

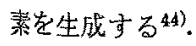

生体内で nitrile がどのるうな化学变化腺するものか くわしいことはわからないが，选元反态によってフミン が生成すれば，比較的急性の害作用を示するのと考えら
れる、 nitrile が示す強い害作用は，生体内で有整なアミ ン学生成していることを示唆しているように思和る。

\section{グルコシノレート含有飼料の家畜・ 家雷への影響}

glucosinolates 含量の高い飼料として現在最も注目さ れているのはナタネ粕である. glucosinolates の加水分 解物によってひき抗さされる㮔々の生理作用が家望の生 座性に大きく影睤するため, glucosinolates の含量が， ナタネ粕の配合割合を規制する最大の因子となってい る.ナタネ粕の飼料価值安検討した研究報告は非常に多 いが，原料ナタネの種類および搾油方法の違いがその栄

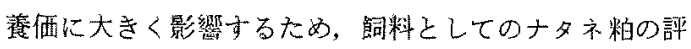
洒は様々である。

\section{1. 家 离}

ナタネ粕を大豆粕の代替物として飼料に配合した場 合，ヒナの成長がかくれ，甲状腺の著しい肥大がみられ たという報告は数多い。上坂ら ${ }^{45}$ は，十タ不粕を $15 \%$ 配

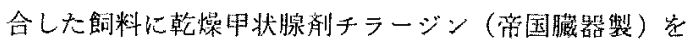
$100 \mathrm{ppm}$ 添加すると，ヒナの甲状腺重量, 組織像ともに 正常に復すること荌琶めたが，発育に対する効果は認め ていない。しかし，ナタ神粮用いる䎏合，エネルギー およびタンバク質を大豆粕配合の場合と同一になるよう に胡製すれば，ヒナの甲状腺は琎大寸るが，成長は大豆 粕配合の場合と同じになることが，多くの研究者によ。 て磪かめられている ${ }^{46-49)}$ ，七ナの甲状腺の肥大度と增体 量との間に，相関関係は存在していないので，ナタネ粕 給与による甲状腺の肥大分，成長阻害因子の存在安示唆

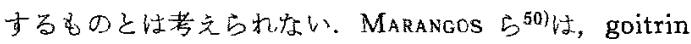
を全く合まない力ラシ粕（B区），goitrit 含量が小（C 区)，中（D区）执よび大 ( E区) 3 種の十多粕定， 産卵鷂用の飼料にいずれも $12 \%$ 配合し，産卵開始後 6 加月の雑種 (H and N Nick Chicks) を用いて，12 週 間の飼峜試唤を行なった，刘照区の飼料には大豆粕定夕

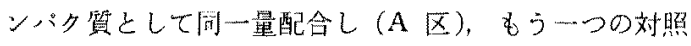
区として市质の配合初料索給与した区（F区）設け， 各区の産畉数，卵重，数死数を比較した。試験期間中 1 日1羽あたりの産卵重は，B区，D区，E区で付意に減

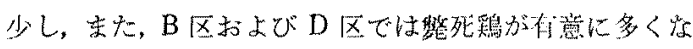

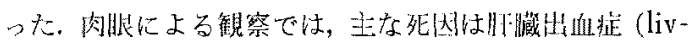
er haemorrhage) によるものと考えられた，試駼終了時 にお子る各区5羽ずっの甲状腺重量の比較では，A区に 比べて，C区は約 2.9 倍，D区は約 4.3 倍，E区は約 8.9 倍となったが，B区はA区とほ济同じであった。産 卵鵎心甲状腚重量は，飼料中の goitrin 含量之密接㳊関 
係していたが，甲状腺の肥大度は，産卵㧍よび整死とは

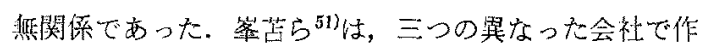
られたナタ稍 A (OZT 0.24\%, ITC 0.83\%), B (OZT $0.07 \%$, ITC $0.08 \%$ ), C (OZT $0.29 \%$, ITC $0.76 \%$ )

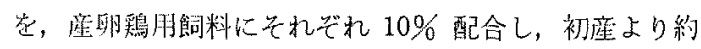
58週間飼養した. OZT 拉よびITC 含量の非常に低いB では，甲状腺はあまり肥大しなかったが，産卵染の低下 や肝臓出血症による然死鵎が，他のナタネ粕（A 扩上び C) と同栚に多加た. SMITH and CAMPBeLL ${ }^{22)}$ にる と, glucosinolate 含量の多いナタネ粕 (Target 種) 給 与した場合は産卵率の低下が大きく, glucosinolate 含量 の少ないナタネ粕（Bronowski 種）の場合は産卵率の低 下が僅かであったが，肝臟出血症の発生率は，いずれの ナタネ粕でむ対照区に比べて有意に高く，雨種のナタネ 粕の閒には差がなかった，一般に，良質なナタネ粕であ

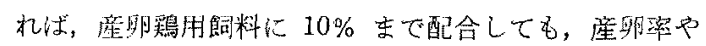
整死率に影響しないるされているが46,52-54)，ナタネ粕の 種類によっては，この程度の配合割合であっても，座卯

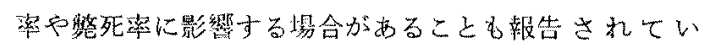

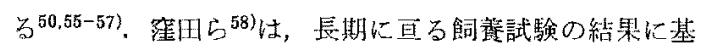
ふいて，ナタネ粕の配合割合は8\%以下にとどめること を推奖している。

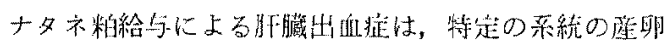

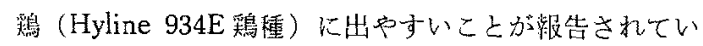

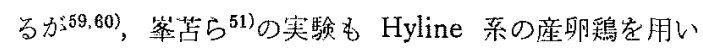
て㧍り，絪喠による造いを梌討する必要があると述べて いる.

ナタ亦粗在酸合した䬣料定給与した場合，㶵㚖い卵 (fishy egg, tainted egg, crabby egg) 生むことがあ る. 単冠白色レダホーン種 (SCWL) ではナタネ斯定絡

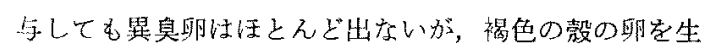
む鵎理ロードフイランドレッド（RIR）采統の産卵鷄で

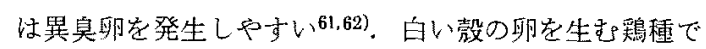

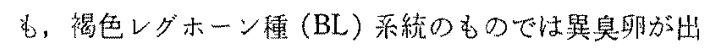
やすいようである62). OVERFIELD and Elson ${ }^{63}$ 仗，ナタ

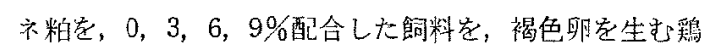
に給与した。ナタ亦粕の配合割合は産卵には影響しなか ったか，3\%湶加区で 1.2\%，6\%添加区で 19.3\%，9\% 源加区では 20.9\%の異臭卵が発生したが，ナタネ粕を 配合しなかった対照区には，翼臭卵は全く発生しなかっ た. 卵の異臭の本体は, trimethylamine であることが HoBSON-FroHOCH and LAND ${ }^{64)}$ とょって確加めらてい る. trimethylamine は動植物方腐敗索る際に生成する塩 基性の気体で，アンモニアに似た臭をるってるが，ナ タネ焻には通常ほとえど存在していない。褐色卵定生む
鷄種では，前駆体の形で接取した trimethylamine の体 内での处理能力が低いためか，あるい忹，trimethyloxydase 阻害图子をもっているためであると考えられてい

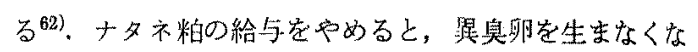
るので, trimethylamine の前駆体が glucosinolates で ある公算は大きいように考えられる. CLANDININら ${ }^{61)}$ は, 異龺卵発生防止の見地加ら，産眆舀用飼料へのナタ ネ粕の配合割合は，5\%以下にとどあることを推楚して いる.

MARCH and BIELY5) ${ }^{65}$ は, ナタネ粕営給与した鵎の産ん だ卵の受精率, 卵化率および孵化後のヒナの発育には, 何ら悪い影響は認められなかったが，緲化直後のヒナの 甲状腺重量が，大豆粕を給与した対照区の鵎の卵から瞕 化したヒナに比べて，犬きくなっているととに気付い た.この場合，䁌化後 4 週間の七ナでは，甲状腺重量壮 正常のものとかわりなかった. ROAS and CLANDiniN66. 67) は，ナタネ粕の glucosinolates の加水分解物が卯へ移 行することを照念して，ナタネ晄を多量に給与した鷄の 生んだ眀について，OZT，ITC および nitriles の分析を 行なったが，卵の中にその存在を確かめえなかった。 そ

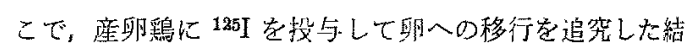
果,ナタネ粕を給与した産卵鵎では, ヨウ素の卵への移 行が減少していることが傕かめられた。徒って，十名

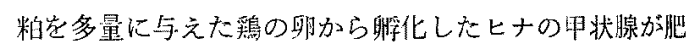
大しているのは，ヨウ素の不足に起因しているものと推

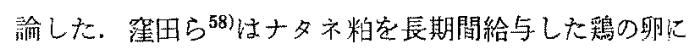
ついて, 抗甲状腺物質の有且をヒナの飼養試駼によって

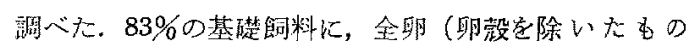
で，水分約 74\%）属乾物（水分 $12 \%$ ）として $17 \%$ 相 当になるように混合し，室温で通風乾燥後粉化して，初 生ヒナに 4 週間給与したが，甲状腺の肥大以認められな 加った.ナタネ粕に含まれている glucosinolates の加水

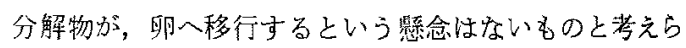
れる.

\section{2. 豚}

HUSSAR and BOWLAND ${ }^{68}$ ) 埸合の抗甲状腙作用定報告し, MANNS and BowLAND ${ }^{69 ?}$ は、長期間ナタネ稙を給与すると，血中の protein-bound iodine (PBI) が減少することをみている，JOSEFSSON70) によると，豚は glucosinolates の分解生成物に比㛺的敏 感であるという理由から，スェーデンでは養豚用配合飼 料に用いるナタネ粕の媓は，多くの場合 $1 \%$ 以下にして いるようである. BowLAND ${ }^{71}$ によると，カナダでは体重 $25 \mathrm{~kg}$ までの幻い豚では 4\%まで，25９0 kg までの豚 に対しては10\%までナタネ粕を配合しても差支えない。 
ここで示した䈀囲内での使用であれば, ナタネ粕は市場

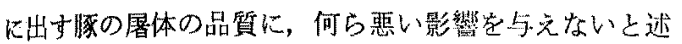

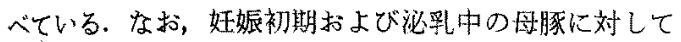
は、ナタネ粕の配合割合は 3\%をこえてはならないとし ていたが, SABEN and BoWLAND ${ }^{72}$ 怯, B. campestris 采の

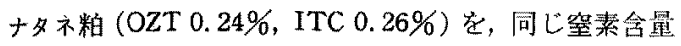
の大豆粕のかわりに，4\%をたは8\%飼料に配合して，妅 娠中⿰よび泌乳中の母豚に給与し，この程度のナタネ粕 の配合割合でも，豚の繁殖に何ら悪い影響を与えないこ 々を確かめている。かが国では, 估野ら のナタネを原料化して，日本の擦油工場 3 籄所で製造さ れた 3 種類のナタネ粕をそれぞれ 10\%配合した飼料を 用い，豚産肉能力検定の実施要領に準じて，肉豚の肥育 試験を行なった. 甲状腺ならびに肝膩の重量は,ナタネ 粕配合飼料の給与によって有意に增加したが，居体の肉 質や脂肪などには，ナタネ粕給与の影響は認められなか った. 使用した 3 種類のナタネ粕は，色合いや水溶性窒 素指数の点では，それでれ異なっていたが，飼料の搘好 性技よび豚の発育，屠体の品質などの諸点からみる限り では，実用上差異はなかった，肉豚用の飼料にナタネ粕 を10\%配合することは可能であると結諭している。

ヨーロッパで栽堷されているナタネは主にB. napus の冬作で，カナダで栽培されているナタネの大部分は B. campestris の夏作である. JOSEFSSON and APPELQViST 74)調查によると, ナ夕亦粕の glucosinolates 含量は,

B. napus の冬作では, 3.39 7.77\%，夏作恃, 3.72〜 5.75\%であったのに対し，B. campestris では，冬作は

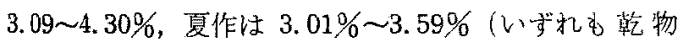
中)となって抢り，一般にB. campestris は B. napusに 此べて glucosinolates が少く, 夏作ナタネは冬作ナタネ よりも glucosinolates が少いとい光ようで方る，铝料 としてのナタネ粕の品質は擦油方法によっても大きく左 右されるが，原料ナタネの glucosinolates 含量が高い か，低いかという裎いが，ナタ亦粕の配合許容限度を決 める上で影響していたように考无られる。

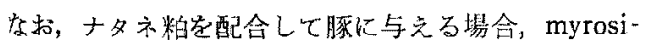
nase source を添加すると，成長阻害が著しく大きくな るという前述の BeLL ${ }^{25)}$ の報告は,ナタ齐粕の glu一 cosinolates 含量とともに，十タ亦粕中に残存している myrosinase 活性の程度, myrosinase 活性をっつ他の配 合原料の有無务，ナタネ粕の飼料価值を大きく左右する ととを示唆している、BELL ら ${ }^{75}$ の実験によると, myrosinase の添加は，ナタネ粕中の glucosinolates 女るいは その分解物の，消化管からの吸收速度を著しく早めるよ らである.

\section{3. 反塲家蓄}

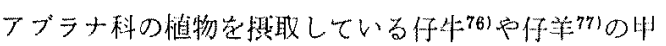

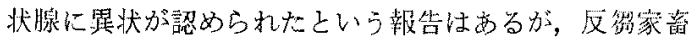
では，ナタネ粕を給与しても，鷄や豚などのように，甲 状腺の異状をきたすこと法少いようである゙78,799。ヨーロ ッパでは，ナタネ粕は古くから飼料として利用されてい るが，スエーデンでは，飼料として使われているナタネ 粕の $80 \%$ 前後は牛の配合飼料原料になっている ${ }^{70}$.

ナタネ粕の給与が，牛自体には影響を与元なくて す，ミルクの品質に影響しないがどうかということは， 当然慎重に検討されるべき問題である. CLEMENTS and WISHARD $^{73)}$ は，フブラナ科の植物である marrowstem kale (Brassica oleracea var moelleria) いる4のミルク中に，甲状腺の1311のとりこみ家阻害す る物質が含まれており，また，オーストラリアの妇状腺 腫発生地带の放牧場には，フブラナ科の雑草が多く、 ルクが甲状腺腫発生の原因となっている可能性夌指摘し た. Peltola and Krusius ${ }^{80-82)}$ も,フィンランドの妇状 腺腫発生地带の牛のミルクについて同様な観察索し、 ルク中に thiouracil，あるいはVTO (goitrin)のような 抗甲状腺物質が存在しているものと推諭した。このよう

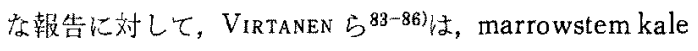

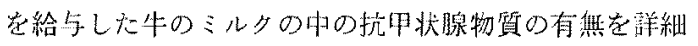
に顺討し，また，PeLtoLAらが調疽したのと同じ甲状牒 唓発生地㴖の，同じ牧場加ら集めたミルクを用いて， PELTOLA の実験を追試し，更に，goitrin あるいは progoitrin 学乳牛に投与して、ミルクへの移行索調心゙るなど

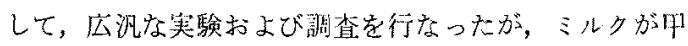
状腺腫誘発の原因になるという証㧹は何も得られなかっ たと述べている. HOPPE ら ${ }^{87}$ は，1 日むたりの泌乳量が $24 \sim 30 \mathrm{~kg}$ の乳牛に, ナタネ粕 (OZT 1.38\%, ITC 0.22 $\left.\%, \mathrm{SCN}^{-} 0.04 \%\right) を 1.8 \mathrm{~kg} /$ 日給与したが，ミルクの 脂肪，固顼物，乳糖，クェン酸拉よび $\mathrm{Cl}^{-}$含量, ならび に，産乳量に何影響がなかった。また，呞料中の OZT および ITCは：ミルクにはほとえど移行しなかった。 thiocyanate $\left(\mathrm{SCN}^{-}\right)$は，落花生粕を与之た刘照区の牛 のミルクでは, $3.64 \mathrm{mg} / \mathrm{l}$ であったが, ナタネ粕給与区 のミルクは $5.71 \mathrm{mg} / \mathrm{l}$ に增加した. VIRTANEN $5^{85.86) の ~}$ 实験炕よると，アブラ十科の植物が飼料中に多量に存在 していても：ミルクリの thiocyanate は $1 \mathrm{mg} \%$ 以上に はならないということである。

乳牛のミルクに，飼料中の抗阵状腺物筫少移行するこ とを肯定する実験も，乙れを否定する笑験も，ともに綿 密，群細比行なわれているので，この問題に結湆がつい たるのと断定するわけにはいかないが，乳牛に対するな 
タネ粕の給与によって，glucosinolates またはその分解 生成物のミルタへの移行が，実際上問題になる稘念は少 いように考芝る。

$$
\text { おわりに }
$$

わが国の油脂事情88)歹ると，昭和50年度における 植物性油脂の生産量の广かで，最も多いのは大豆油の 47 万 2 下トンで，第2位はナタネ油の30 万4干トン，

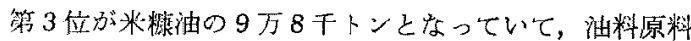
としてのナタネの比重は極めて大きい,ナタネ注油脂の 含量が离いので，控油徭に残る油粕としては，大豆粕が 約 200 ケトンで第 1 位，米棣油粕が約 42 万トンで第 2 位を古め，ナタ不粕结約 40 万トンで第 3 位となってい る. 昭和 42 年度における大豆粕の生産量は 125 万卜ン， 米糠油粕は 38 万トン，十タネ粕的 13 万トンである。 大豆粕の生産量す 1.6 倍に增加したが,ナタ䄸は 3 倍 になっており，その堌加は特に著しい，

飼料として利用されているナタネ粕の量は，䀡和 50 年 塺において約 14 万トンで，飼料化率は約 $35 \%$ である。 大豆粕では約 85\% が，米糠油粕では䄪 73\% が飼料上 して利用されているのに比べると，ナタネ粕の䝭料化繁 は低く，大半は肥料にされている。

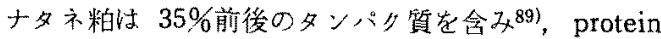
efficiency ratio (PER) はカゼインに比燠 L, 大豆粕より 女高い90)：タンハク筫資源として洒值あるナタネ粕を， 餇料として管分活用していないわ加国の現状は，当它之 てないものといる. glucosinolates 含量の非常に少い Bronowski 種の存在が確認されたのは約 10 年前のこと であるが，その徯，油の中のエルシン酸 $\left[\mathrm{CH}_{3}\left(\mathrm{CH}_{2}\right)_{\tau}\right.$. $\left.\mathrm{CH}=\mathrm{CH} \cdot\left(\mathrm{CH}_{2}\right)_{1]} \cdot \mathrm{COOH}\right]$ の少いもの, 油粗中に glucosinolates の少いもの，という三大目標を目指してナ タネの育種改良は急速に進展し，この耐者ともに少 い“Erglu種”(西ドイッ), “Tower種”(カナダ)など の新品種作り出されている。立た，控油工程の工夫见 よって，タンハク質の栄誉洒の低下を避けながら myrosinase を不活化することも行なるれる一方，ナタ神粨 処理して glucosinolates 積極的に取除いた製品も作ら れるようになってきている。ナタネ油の需要の增加と，

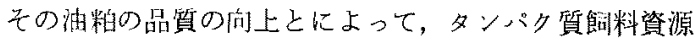

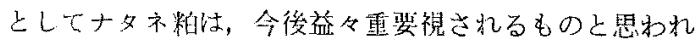
\%.

\section{女 献}

1) Hill, D. C., Rapessed Assoc of Canada, Publ No 40: 53-55. 1976.
2) 長島善次・内山正昭，㤟化 33：980-984. 1969.

3）大鶴 勝, 京都大学食糧科学研究所報告第 38 号, 13-32. 昭和 50 年 3 月.

4) Melvin, E., M.E. Daxenbicher, C. H. VanetTEN, and G. F. Spencer, J Agric Food Chem 25: 121-124. 1977.

5) Kennedy, G, and H. D. Purves, Br J Exp Pathol 22: 241-244. 1941.

6) Astwood, E. B., M.A. Greer, and M. G. ErtrINGER, J Biol Chem 181: 121-129. 1949.

7) Krusius, F.E., and P. Peltola, Acta Endocrinol 53: 342-352. 1966.

8) Langer, P., and N. Michajlovskiji, Acta Endocrinol 62: 21-30. 1969.

9) Clandinin, D. R., and E. W. Tajchar, Poult Sci 39: 291-293. 1961.

10) Akiba, Y., and T. Matsumoto, Poult Sci 55: 716-719. 1976.

11) Clandinin, D. R, L. Bayly, and A. Caballero, Poult Sci 45: 833-837. 1966.

12) Akiba, Y, and T. Matsumoto, Tohoku. J Agric Res 23: 79-85. 1972.

13) Akrba, Y, and T. Matsumoto, Tohoku J Agric Res 23: 86-91. 1972.

14). Matsumoto, T., H. Itoh, and Y. Akiba, Poult Sci 47: 1323-1330. 1968.

15) Pitt-Rivers, R., and R. R. Cavalieri, in The Thyroid Glanded by R. PItT-Rivers and W. R. Trotter Vol 1. 87-112, Butterworths, London. 1964.

16) AкiвA, Y., and T. Matsumoto, Tohoku J Agric Res 22: 189-197. 1971.

17) Акıва, Y., and T. Matsumoto, Jap J Zootech Sci 投稿申

18) Lo, M. T, and D. C. HiLl, J Nutr 101: $975-980$. 1971.

19) Lo, M. T., and J. M. Bell, Can J Anim Sci 52: 295-302. 1972.

20) Lo, M. T., and D.C. Hill, Can J Anim Sci 51: 187-192. 1971.

21) Iino, S., Acta Endocrinol 36: 212-220, 1961.

22) Smith, T.K., and L. D. Campbell, Poult Sci 55: 861-867. 1976.

23) Greer, M. A, and J. K. Deeney, J Clin Invest 38: 1465-1474. 1959.

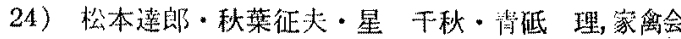
誌 12: 265-269. 1975.

25) Bell, J. M., J Anim Sci 24: 1147-1151. 1965.

26) Peltola, P., and F-E. Krusius, Experimenta 25: 1328-1329. 1969.

27) BeLl, J. M., Can J Anim Sci 37: 43-49. 1957.

28）林 国興・秋葉征夫・松本達郎，栄養と食糧 25: 72-78, 1972.

29）秋葉征夫・松本達郎，栄竛亡食糧 28：457-461. 1975 . 
30) BeLl, J. M. Can J Anim Sci 37: 31-42. 1957.

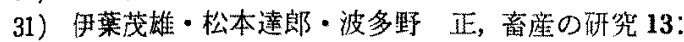
441-442. 1959.

32) Pitt-Rivers, R., Physiol Rev 30: 194-205, 1950.

33) Dow, D.S., and C.E. Allen, Can J Agric Sci 34: 607-613. 1954.

34) Kratzer, F.H., P.N. Davis, D. E. Williams, and B. J. Marshall, J Nutr 53: 407-419. 1954.

35) Klain, G. T., D. C. Hill, H. D. Branion, and J. A. Gray, Poult Sci 35: 1315-1326. 1956.

36) Clandrin, D. A., and L. Bayly, Poult Sci 39: 1239-1240. 1960. (Abstr).

37）森脇甲介・川口幸一・井口新一郎, 京都大学鋠学部 畜産学教公創設 25 年記念論文集, 20-24, および， 25-31. 1961.

38) Langer, P., Physiol Bohemoslov 13: 542-549. (Nutr Abstr Rev 35: 2275. 1965 による)

39) LANGER, P., Endocrinol 79: 1117-1122. 1966.

40) Gmelin, R., and A. J. Virtanen, Suom Kemistil 32B: 236. 1959. (Chem Abstr 55: 13553f. 1961 による)

41）柴田 浩・池田三義, 日獣誌 32：1-9. 1970.

42) Akiba, Y., and T. Matsumoto, Jap J Zootech Sci 47: 679-683. 1976.

43) Vanetten, C. H., W. E. Gagne, D. J. Robbins, A. N. Booth, M. E. Dexenbichler, and I. A. Wolf, Cereal Chem 16: 145-155. 1969.

44）方来崎爰，大有機化学 (小竹舆二雄監修)，第 4 巻： 280 , 朝含書店. 果京. 1967.

45）上坂章次 - 川島良治 - 加藤啓介 - 大崎豊应 - 阙田 通子，日畜会報 35：特別号：167-172. 1964.

46) Clandinin, D. R., Canada Dept of Agric, Publ 1257: 81-96. Queen's Printer and Controller of Stationary, Ottawa, Canada, 1965.

47）中谷哲郎, 日音会報 40：18-24. 1969.

48）中谷哲郎，日畜会報 40：25-31。 1969.

49) Anwar, A., D. R. Clandinin, and A. R. Roblee, Poult Sci 50: 181-183. 1971.

50) Marangos, A., R. Hill, B. M. Laws, and D. Muschamp, Br Poult Sci 15: 405-414. 1974.

51）㟄苫稔三・黑田修平・日浅文男 - 楢橋網雄 - 伊藤 隆・寺山照也，第 80 回 日本獸医学会(昭和 50 年 11 月), 講演要旨: 153. 1975 .

52）窪田大作・箖本 客, 家禽会誌 6：36-39. 1969.

53) Clandinin, D. R., Rapeseed Assoc of Canada, Publ No 32: 68-71. 1973.

54) Summers J. D., Rapeseed Assoc of Canada, Publ 32: 75-79. 1973.

55) Jackson, N., J Sci Food Agric 20: 734-740 1969.

56) Summers, J. D., G. Rajarantam, and W. F. PepPER, Poult Sci 50: 1382-1386. 1971.

57) March, B. E., J. Biely, and R. Soong, Poult Sci 51: 1589-1596. 1972.

58）徒田大作・土黑定信 - 久保辰雄・松島正洋 - 野口 進・今井一郎・飯野雅夫・平野公夫・田家渆一, 家
谓会誌 9: 274-280. 1972.

59) Slinger, S. L., Repeseed Assoc of Canada, Publ No 40: 84-85. 1976.

60) Slinger, S. L., Rapeseed Assoc of Canada, Publ No 40: 89-91. 1976.

61 Clandinin, D. R., M. Z. Hawrysh, J. H. Howell, J. A. Hanson, R. G. Christian, and G. Mile, Rapeseed Assoc of Canada, Publ No 40:79-81. 1976.

62) Bolton, W. T., T. G. Carter, and R. M. Jones, Br Poult Sci 17: 313-320. 1976.

63) Overfibld, N. D., and H. A. Elson, Br Poult Sci 16: 213-217. 1975.

64) HoBson-FrOHOCH, A., D. G. LAND, N. M. GRIFFITHS, and R.F. Curtis, Nature (London) 243: 304-305. 1973.

65) March, B. E., and J. Brely, Rapeseed Assoc of Canada, Publ No 32: 71-75, 1973.

66) Roas, A. J., and D. R. Clandinin, Br Poult Sci 16: 413-415. 1975.

67) Roas, A. J., and D.R. Clandinin, Rapeseed Assoc of Canada, Publ No 40: 56-58, 1976.

68) Hussar, N., and J. P. Bowland, Can J Anim Sci 39: 84-89. 1959.

69) Manns, J.G., J. P. Bowland, V.E. Mendel, and S. Zivкоvic, Can J Anim Sci 43: 271-278. 1963.

70) Josefsson, E., in "Rapeseed" pp 371-375. ed by L-A. Appelquist, and R. Ohlson, Elsevier Publ Co, Amsterdam, London, New York, 1972.

71) Bowland, J.P., Canada Dept of Agric, Publ 1257: 69-80. Queen's Printer and Controller of Stationary, Ottawa, Canada, 1965.

72) Saben, H.S., and J.P. Bowland, Can J Anim Sci 51: 225-232. 1971.

73）货野 修・福田 勤・中谷哲郎・田上末四郎・久 池井忠男, 日豚研誌 8：109-115. 1971.

74) Josefsson, E., and L-A. Appelquist, J Sci Food Agric 19: 564-570. 1968.

75) Bell, J. M., C.G. Youngs, and R. K. Downey, Can J Anim Sci 51: 259-269. 1971.

76) Clements, F.W., and J. W. Wishart, Metabolism 5: 623-639. 1956. (Nutr Abstr Rev 27: 2566. 1957.による)

77) Russel, A. J. F., Animal Prod 9: 131-133. 1967.

78) Bell, J.M., Canada Dept of Agric, Publ No 1257: 52. Queen's Printer and Controller of Stationary, Ottawa, Canada. 1965.

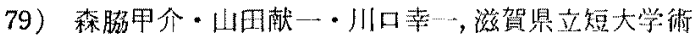
雑誌，第 1 号：44-48，绝和 35 年.

80) Peltola, P., and F-E. Krusius, Acta Endocrinol 33: 603-612. 1960.

81) Krusius, F-E., and P. Peetola, Acta Endocrinol 53: 342-352. 1966.

82) Arstila, A., F-E. Krusius, and P. Peltola, Acta Endocrinol 60: 712-718. 1969. 
83) Virtanen, A. I., M. Kreula, and M. Kiesvaare, Acta Chem Scand 13: 1043-1044. 1959.

84) Virtanen, A. I., M. Kreula, and M. Kiesvaare, Z. Ernaehrungswiss Supple 3: 23-37. 1963. (Nutr Abstr Rev, 34: 613. 1964. による).

85) Virtanen, A. I, and R. Gmelin, Acta Chem Scand 14: 941-943. 1960.

86) Purronen, E., and A. I. Virtanen, $Z$ Ernaehrungswiss 3: 140-147. 1963, (Chem Abstr, 59:4319d. 1963. による)
87) Hoppe, K., H. Kozlowska, and A. RutKowski, Milchwiss 26: 19-23. 1971.

88）農林省食品油脂課，“わが国の油脂事情”昭和 51 年.

89）農林省軖林水産技術会議事務局，“日本標潄飼料 成分表（1975 年版）”中央畜産会・東京，䀡和 50 年.

90) Bell, J. M., P. Grovannetti, T.F. Sharby, and J.D. Jones, Can J Anim Sci 56: 763-768. 1976. 